\title{
The utility of nerve conduction studies in patients with diabetic polyneuropathy
}

\section{Przydatność badań neurograficznych u chorych z neuropatią cukrzycową}

MARTA BANACH ${ }^{\mathrm{A}-\mathrm{G}}$

Klinika Neurologii Uniwersytetu Jagiellońskiego Collegium Medicum

A - Study Design, B - Data Collection, C - Statistical Analysis, D - Data Interpretation, E - Manuscript Preparation, $\mathbf{F}$ - Literature Search, $\mathbf{G}$ - Funds Collection

Summary Background. Neuropathy is one of the most common, debilitating complications of diabetes mellitus, often neglected in routine diabetes treatment. It is the single most common reason for foot ulcerations and amputations and is responsible for severe sensory abnormalities and reduced quality of life among thousands of diabetic patients.

Objectives. The aim of our study was to establish the prevalence and type of peripheral neuropathy in diabetic patients by means of nerve conduction studies (NCSs) in order to encourage primary care physicians to look for any signs of sensory or motor abnormalities early in the management of diabetes, thus preventing irreversible nerve damage.

Material and methods. A total of 21 patients with type 2 diabetes (12 men and 9 women; mean age, $60.8 \pm 8.9$ years) presenting with neuropathy symptoms were enrolled into the study. Sensory and motor NCSs were conducted in the ulnar, median, peroneal, sural, and tibial nerves.

Results. Sensory axonal polyneuropathy was diagnosed in 7 patients; sensory and motor polyneuropathy, in 2 patients; and carpal tunnel syndrome, in 3 patients. In the remaining patients, the results of NCSs were within the reference range.

Conclusions. The study revealed that 12 patients $(57 \%)$ had nerve conduction abnormalities suggesting peripheral nerve changes and polyneuropathy. In addition, our study confirmed that NCSs are useful in assessing the prevalence of neuropathy and differentiating between axonal and demyelination polyneuropathies and various types of mononeuropathies in diabetic patients and should be part of routine primary care protocols in the management of diabetes.

Key words: type 2 diabetes mellitus, nerve conduction studies, diabetic polyneuropathy.

Streszczenie Wstęp. Neuropatia jest jedną z najczęstszych, najbardziej uciążliwych powikłań cukrzycy, często zaniedbywana podczas rutynowych kontroli lekarskich. Neuropatia jest najczęstszą przyczyną owrzodzeń oraz amputacji stóp oraz przyczynia się do ciężkich zaburzeń czucia i obniżonej jakości życia tysięcy pacjentów z cukrzycą. Wczesne wykrycie oraz odpowiednio szybko podjęte leczenie jest kluczowe w złagodzenia objawów i zahamowaniu postępu choroby, zapobiegając w ten sposób trwałym, nieodwracalnym uszkodzeniom nerwów

Cel pracy. Określenie przydatności badania przewodzenia nerwowego (NCS) w ocenie częstości występowania neuropatii oraz określenia jej rodzaju u chorych na cukrzycę, tak aby zwiększyć świadomość lekarzy pierwszego kontaktu o istocie problemu i uczulić na towarzyszące cukrzycy objawy zaburzeń układu nerwowego.

Materiał i metody. W badaniu wzięło udział dwudziestu jeden pacjentów chorych na cukrzycę typu 2 (12 mężczyzn i 9 kobiet; średnia wieku $60,8 \pm 8,9$ roku) z objawami neuropatii. Wykonano badanie przewodzenia czuciowego (SNCS) w nerwach: łokciowym, pośrodkowym, strzałkowym powierzchownym i łydkowym oraz badanie przewodzenia ruchowego (MNCS) w nerwach: łokciowym, pośrodkowym, strzałkowym i piszczelowym z uwzględnieniem fali F. U wszystkich chorych przeprowadzono wcześniej kliniczne badanie neurologiczne.

Wyniki. Zespół cieśni nadgarstka rozpoznano u trzech pacjentów, aksonalną polineuropatię czuciową rozpoznano u siedmiu pacjentów, a polineuropatię czuciowo-ruchową typu aksonalno-demielinizacyjnego - u dwóch pacjentów. $U$ pozostałych pacjentów parametry przewodzenia były prawidłowe.

Wnioski. Wyniki wykazały, że neuropatia występuje powszechnie u chorych na cukrzycę oraz potwierdziły przydatność badania neurograficznego w ocenie występowania, a także rozpoznawania odmiennych typów neuropatii cukrzycowej od polineuropatii aksonalnych i demielinizacyjnych oraz różnego rodzaju mononeuropatii. Opierając się na naszych wynikach postulujemy, aby badanie neurograficzne stanowiło integralną część badań podstawowych przy leczeniu cukrzycy.

Słowa kluczowe: cukrzyca typu 2, badanie neurograficzne, polineuropatia cukrzycowa.

\section{Background}

Diabetic neuropathy is the most common neurological complication of diabetes, affecting up to $50 \%$ of all diabetic patients worldwide. Research on the population in Rochester found that $1.3 \%$ of individuals had diabetes, of which $54 \%$ presented with symptoms of polyneuropathy (7 in every 1.000 persons). Diabetic neuropathy is a significant problem for primary care practitioners. According to studies of Italian primary care practitioners, its prevalence in a population over 55 years of age reaches $1 \%$. The prevalence rate increases with age and duration of the disease $[1,2]$.

Sensorimotor peripheral polyneuropathy is the most common type of diabetic neuropathy. Comorbidities often include autonomic neuropathy. The onset of the disease is usually insidious. 
Patients with diabetic neuropathy typically have symmetric numbness, tingling, and pain (stocking and glove distribution). The sensory symptoms include those linked to thick fibers, such as a decrease of tendon reflexes and vibratory sensation in the leg.

Moderate and severe diabetic neuropathy is associated with the risk of weakness in the feet that spreads proximally. It is the single most common reason for foot ulcerations and amputations and is responsible for severe sensory abnormalities and reduced quality of life in thousands of diabetic patients [3-5]. Early detection and treatment is the key to alleviating symptoms of neuropathy and stopping the progression of the disease, which prevents permanent and irreversible nerve damage [6].

Routine monitoring of diabetic patients is often limited to a regular measurement of blood glucose levels and cardiovascular checkup, often neglecting the follow-up of other possibly affected systems such as the peripheral nervous system. Diabetic patients are referred to neurological clinics only when neuropathy symptoms are already severe and difficult to manage [7].

A nerve conduction study (NCS) is a reliable, noninvasive, and highly reproducible method that is routinely used in the diagnosis of peripheral nerve disorders. The utility of NCSs for detecting peripheral nerve changes has been shown in numerous disorders, allowing for the implementation of relevant treatment protocols and prevention of further damage. Abnormalities in the sensory fibers occur in $89 \%$ of patients with clinical symptoms of polyneuropathy, while those in the motor fibers - in $78 \%$ to $80 \%$ of the patients. Axonal injury occurs first, while segmental demyelination is secondary. A reduction in nerve conduction velocity by more than $20 \%$ to $30 \%$ of the normal value is caused by the coexistent demyelination and metabolic factors $[8,9]$.

\section{Objectives}

The aim of our study was to establish the prevalence and type of peripheral neuropathy in patients with type 2 diabetes using the NCS in order to encourage primary care physicians to examine any signs of sensory or motor abnormalities early in the diabetes treatment to prevent irreversible and debilitating nerve damage.

\section{Material and methods}

\section{Subjects}

The study included 21 patients with type 2 diabetes (12 men and 9 women; mean age, $60.8 \pm 8.9$ years). The duration of type 2 diabetes ranged from 7 weeks to 25 years. Patients did not have any other risk factors for neuropathy. All patients reported symptoms suggesting neuropathy, such as dysesthesia, numbness, or sensory loss in the feet or hands (or both).

A neurological examination revealed abnormalities in 12 patients, including a decrease in ankle jerks and vibratory sensation in the legs. Additionally, in 6 of these patients, sensory loss was observed, with symmetrical glove and stocking distribution.

All patients provided written informed consent to participate in the study, and the study protocol was approved by the local ethics committee.

\section{Stimulation technique}

NCSs were conducted according to standard procedures using the Viking Quest device (Nicolet Biomedical Incorporated, Madison, WI, USA).
Sensory NCSs (SNCSs) were conducted in the ulnar, medial, sural, and peroneal nerves. A median sensory NCS was recorded with wire electrodes from the second digit antidromically with a standard distance of $13 \mathrm{~cm}$, and the fifth digit with a standard distance of $12 \mathrm{~cm}$. In the lower extremities, the antidromic method was used to stimulate the sural nerve laterally to the midline of the calf muscles and the superficial peroneal nerve with stimulation electrodes placed against the anterior edge of the fibula.

Motor NCSs (MNCSs) were conducted in the ulnar, median, peroneal, and tibial nerves with a single stimulus and with a stimulation rate of $1 \mathrm{~Hz}$ to obtain the $\mathrm{F}$ wave. In the upper extremities, stimulations were conducted over the left ulnar and right median nerves. In the lower extremities, stimulations were conducted over the right peroneal and left tibial nerves. The intensity of the current and the site of stimulation were set according to the standard protocol.

Supramaximal, constant-current bipolar stimulation was conducted using a bar electrode and ring electrodes. SNCSs were conducted using a stimulation rate of $2 \mathrm{~Hz}$, while MNCSs - using single, rectangular pulses. The stimulus duration was $0.2 \mathrm{~ms}$.

\section{Data analyses}

Only descriptive statistics were used in the study.

\section{Results}

\section{Clinical examination}

All patients reported symptoms suggesting neuropathy, such as dysesthesia, numbness, or sensory loss in the feet or hands (or both). Two patients also reported distal muscle limb weakness.

A neurological examination revealed abnormalities in 21 patients, such as a decrease in ankle jerks or vibratory sensation in the legs (12 patients), sensory loss in the distal parts of the limbs (7 patients), or weakness and atrophy of the distal muscles of the limbs (2 patients).

Laboratory tests showed normal levels of creatinine phosphokinase and hepatic and thyroid enzymes.

\section{Electrophysiological examination}

A reduction in the amplitude of sensory nerve action potentials (SNAPs) and compound muscle action potentials in the lower limbs was the most common and was more advanced than the generally normal or moderate reduction in sensory and motor fiber conduction velocity. The lack of excitability in single nerves was diagnosed in 3 patients. We confirmed the lack of SNAPs in the sural nerve in 1 patient and in the superficial peroneal nerve in 2 patients. None of the patients showed signs of conduction block.

Sensory axonal polyneuropathy was diagnosed in 7 patients; sensory and motor polyneuropathy, in 2 patients; and compression mononeuropathies such as carpal tunnel syndrome, in 3 patients (Tab. 1). In the remaining patients, the results of the SNCSs and MNCSs were within the reference range.

\section{Discussion}

Our study revealed that 12 patients (57\%) had nerve conduction abnormalities suggesting peripheral nerve changes and polyneuropathy. In the remaining patients, despite clinical manifestations of neuropathy, the NCS did not show any abnormalities, suggesting that the underlying nerve changes present in these patients were likely limited to small fibers, undetectable by standard NCSs $[6,8]$. 


\begin{tabular}{|c|c|c|c|c|}
\hline \multirow{2}{*}{$\begin{array}{l}\text { Patient } \\
\text { No. }\end{array}$} & \multirow{2}{*}{$\begin{array}{l}\text { Nerve distribution of ab- } \\
\text { normalities }\end{array}$} & \multicolumn{2}{|l|}{ Type of abnormalities } & \multirow[t]{2}{*}{ Results } \\
\hline & & SNCS & MNCS & \\
\hline 1 & R median & $\begin{array}{l}\downarrow \text { CNAP amplitude, } \downarrow \text { NCV } \\
\text { finger - wrist segment }\end{array}$ & $\uparrow \mathrm{DML}$ & carpal tunnel syndrome \\
\hline 12 & $\begin{array}{l}\text { L ulnar, } R \text { median, } L \text { sural, } \\
\text { R superficial peroneal }\end{array}$ & $\downarrow$ CNAP amplitude & none & $\begin{array}{l}\text { sensory, axonal polyneu- } \\
\text { ropathy }\end{array}$ \\
\hline 4 & R median & $\begin{array}{l}\downarrow \text { CNAP amplitude, } \\
\downarrow \text { NCV finger - wrist segment }\end{array}$ & $\uparrow \mathrm{DML}$ & carpal tunnel syndrome \\
\hline 6 & $\begin{array}{l}\text { R median, } L \text { sural, } \\
R \text { superficial peroneal }\end{array}$ & $\downarrow$ CNAP amplitude & none & $\begin{array}{l}\text { sensory, axonal polyneu- } \\
\text { ropathy }\end{array}$ \\
\hline 9 & R median & $\begin{array}{l}\downarrow \text { CNAP amplitude, } \\
\downarrow \text { NCV finger - wrist segment }\end{array}$ & $\uparrow \mathrm{DML}$ & carpal tunnel syndrome \\
\hline 10 & $\begin{array}{l}\text { R median, } L \text { sural, } \\
R \text { superficial peroneal }\end{array}$ & $\downarrow$ CNAP amplitude & none & $\begin{array}{l}\text { sensory, axonal polyneu- } \\
\text { ropathy }\end{array}$ \\
\hline 11 & $\begin{array}{l}\text { L ulnar, } R \text { median, } L \text { sural, } \\
\text { R superficial peroneal }\end{array}$ & $\downarrow$ CNAP amplitude & none & $\begin{array}{l}\text { sensory, axonal polyneu- } \\
\text { ropathy }\end{array}$ \\
\hline 13 & $\begin{array}{l}\text { R median, } L \text { sural, } \\
R \text { superficial peroneal }\end{array}$ & $\downarrow$ CNAP amplitude & none & $\begin{array}{l}\text { sensory, axonal polyneu- } \\
\text { ropathy }\end{array}$ \\
\hline 15 & $\begin{array}{l}\text { R median, } L \text { sural, } \\
\mathrm{R} \text { superficial peroneal }\end{array}$ & $\downarrow$ CNAP amplitude & none & $\begin{array}{l}\text { sensory, axonal polyneu- } \\
\text { ropathy }\end{array}$ \\
\hline 16 & $\begin{array}{l}\text { L ulnar, } R \text { median, } \\
\text { R superficial peroneal }\end{array}$ & $\downarrow$ CNAP amplitude & none & $\begin{array}{l}\text { sensory, axonal polyneu- } \\
\text { ropathy }\end{array}$ \\
\hline 18 & $\begin{array}{l}\text { L ulnar, R median, L sural, } \\
\text { L tibial, R peroneal, } \\
\text { R superficial peroneal }\end{array}$ & $\begin{array}{l}\downarrow \text { CNAP amplitude } \\
\text { unobtainable } L \text { sural and } \\
\text { R superficial peroneal }\end{array}$ & $\begin{array}{l}\downarrow \mathrm{CMAP} \text { amplitude } \\
\downarrow \mathrm{NCV} \uparrow \mathrm{DML}\end{array}$ & $\begin{array}{l}\text { sensory and motor polyneu- } \\
\text { ropathy }\end{array}$ \\
\hline 20 & $\begin{array}{l}\text { L ulnar, } R \text { median, } L \text { sural, } \\
\text { R peroneal, R superficial } \\
\text { peroneal }\end{array}$ & $\begin{array}{l}\downarrow \text { CNAP amplitude } \\
\text { unobtainable } R \text { superficial } \\
\text { peroneal }\end{array}$ & $\begin{array}{l}\downarrow \mathrm{CMAP} \text { amplitude } \\
\downarrow \mathrm{NCV} \uparrow \mathrm{DML}\end{array}$ & $\begin{array}{l}\text { sensory and motor polyneu- } \\
\text { ropathy }\end{array}$ \\
\hline
\end{tabular}

$\downarrow$ - decrease; $\uparrow$ - prolongation; L - left; R - right; SNCS - sensory nerve conduction study; MNCS - motor nerve conduction study; CNAP - compound nerve action potential; NCV - nerve conduction velocity in meters/second; DML - distal motor latency in milliseconds; CMAP - compound muscle action potential.

Diabetic neuropathy is characterized by a decrease in nerve conduction velocity and nerve action potential due to axonal loss and fiber demyelination $[10,11]$. NCSs are a helpful tool in the early diagnosis of peripheral neuropathies in diabetic patients. A large cohort study, conducted on several thousands of diabetic patients, indicated that an NCS is the single most reliable predictor of neuropathy risks and could be used as a valuable risk assessment tool differentiating patients according to the risk of neuropathy development, allowing for the implementation of relevant treatment protocols. The final type of neuropathy is also influenced by genetic factors and the age of patients, which condition individual sensitivity to tissue injury, depending on hyperglycemia or hyperinsulinemia [6].

NCSs are very accurate in the early diagnosis of large fiber focal lesions and are particularly useful in a differential diagnosis between axonal and demyelinating neuropathies, both of which require different management and treatment protocols [8]. In our study, patients with detected neurographic abnormalities showed signs of axonal (mainly sensory) polyneuropathy or carpal tunnel syndrome (or both), confirming the results of clinical observations and supporting the role of an NCS in the diagnosis of neuropathy. However, we were unable to detect any nerve conduction changes in the remaining patients. Based on our previous studies and reports by other authors, it might be speculated that those patients suffered from small-fiber sensory neuropathy that requires a collection of nerve biopsies and a subse- quent histological examination in order to establish a proper diagnosis $[12,13]$.

\section{Limitations of the study}

Our study also indicated that NCSs have their limitations. In particular, they fail to detect small-fiber neuropathies, in which case additional diagnostic techniques such as quantitative sensory testing and skin biopsy with quantification of somatic intraepidermal nerve fibers should be used. Because the study group was small, the clinical and electrophysiological correlations were not assessed. Our findings are preliminary.

\section{Conclusions}

Our results showed that an NCS is a reliable tool in establishing the diagnosis and determining the type of neuropathy, differentiating between axonal and demyelination polyneuropathies and different types of mononeuropathies. Based on our results, we believe that NCSs, despite their limitations, should be a part of routine primary care protocols in the management of diabetes. We strongly recommend that all primary care physicians dealing with diabetic patients should monitor the signs and symptoms of nervous system abnormalities and include NCS as part of early diabetes management. 
Source of funding: This work was funded by the author's resources.

Conflict of interest: The author declares no conflict of interests.

\section{References}

1. Said G. Diabetic neuropathy - a review. Nat Clin Pract Neurol 2007; 3: 331-340.

2. Vinik Al, Nevoret ML, Casellini C, et al. Diabetic neuropathy. Endocrinol Metab Clin North Am 2013; 42: 747-787.

3. Vinik AI. Management of neuropathy and foot problems in diabetic patients. Clin Cornerstone 2003; 5: 38-55.

4. Tölle T, Xu X, Sadosky AB. Painful diabetic neuropathy: a cross-sectional survey of health state impairment and treatment patterns. J Diab Complic 2006; 20: 26-33.

5. Clayton W, Elasy TA. A review of the pathophysiology, classification, and treatment of foot ulcers in diabetic patients. Clin Diab 2009; 27: 52-58.

6. Kong X, Lesser EA, Potts FA, et al. Utilization of nerve conduction studies for the diagnosis of polyneuropathy in patients with diabetes: a retrospective analysis of a large patient series. J Diab Sci Technol 2008; 2: 268-274.

7. Herman WH, Kennedy L. Underdiagnosis of peripheral neuropathy in type 2 diabetes. Diab Care 2005; 28: 1480-1481.

8. Mallik A, Weir Al. Nerve conduction studies: essentials and pitfalls in practice. J Neurol Neurosurg Psychiatry 2005; 76(Suppl. 2): ii23-ii31.

9. Gutmann L. Pearls and pitfalls in the use of electromyography and nerve conduction studies. Semin Neurol 2003; $23: 77-82$.

10. Mulder DW, Lambert EH, Bastron JA, et al. The neuropathies associated with diabetes mellitus. A clinical and electromyographic study of 103 unselected diabetic patients. Neurology 1961; 11(Pt 1): 275-284.

11. Perkins B, Bril V. Electrophysiologic testing in diabetic neuropathy. Handb Clin Neurol 2014; 126: 235-248.

12. Saperstein DS, Levine TD, Levine M, et al. Usefulness of skin biopsies in the evaluation and management of patients with suspected small fiber neuropathy. Int J Neurosci 2013; 123: 38-41.

13. Joint Task Force of the EFNS and the PNS. European Federation of Neurological Societies/Peripheral Nerve Society Guideline on the use of skin biopsy in the diagnosis of small fiber neuropathy. Report of a joint task force of the European Federation of Neurological Societies and the Peripheral Nerve Society. J Peripher Nerv Syst 2010; 15: 79-92

Address for correspondence:

Dr n. med. Marta Banach

Klinika Neurologii UJ CM

ul. Botaniczna 3

31-503 Kraków

Tel.: +48 12 424-86-13

E-mail: martabanach@yahoo.com

Received: 13.08 .2015

Revised: 25.08.2015

Accepted: 25.08 .2015 